\title{
Microclimate and Water Conditions of an Extracted and Natural Raised Bog
}

\author{
Jan Zarzycki' ${ }^{1}$ Barbara Skowera', Ewelina Zając $c^{2 *}$ \\ 1 Department of Ecology, Climatology and Air Protection, Faculty of Environmental Engineering and Land \\ Surveying, University of Agriculture in Krakow, Al. Mickiewicza 24-28, 30-059 Kraków, Poland \\ 2 Department of Land Reclamation and Environmental Development, Faculty of Environmental Engineering \\ and Land Surveying, University of Agriculture in Krakow, Al. Mickiewicza 24-28, 30-059 Kraków, Poland \\ * Corresponding author's e-mail: ewelina.zajac@urk.edu.pl
}

\begin{abstract}
The aim of the study was to assess the hydrological and microclimatic parameters in the areas at different stages of succession after the discontinuation of peat extraction relative to the conditions on a natural raised bog (OrawaNowy Targ Basin, Poland). Understanding these conditions is necessary for the effective reclamation of degraded peatlands. Three measurement points were designated in the study area: one on the non-degraded dome of the bog and two in post-mining areas in different stages of succession (Sector A with pine and birch woodland; Sector B with cotton-grass and ericaceous shrubs). Continuous measurements of the water table level, precipitation and air temperature and humidity were performed between May and October in the year 2016. The air temperature throughout the warm half of the year significantly influenced the groundwater levels, as it is the main factor directly affecting evapotranspiration. The effect of the amount of rainfall on the water level proved significant in the post-mining areas, but not significant for the dome of the bog. Under the conditions of an undegraded peat bog, the upper layer, consisting of live and partially decomposed Sphagnum mosses, limits the water level fluctuations by reducing the evaporation from the surface during periods of low water levels, which is caused by a high water storage capacity and reduced infiltration. In advanced stages of secondary forest succession, trees reduce the evapotranspiration from the surface, which reduces fluctuations in the water level; however, by taking up a large amount of water from the deeper layers, they lower it significantly. The greatest effect of the weather conditions on the water level fluctuations occurs at the stage in which the bog is overgrown by shrubs, when there is no natural peat layer, and the impact of shrubs is much smaller than that of trees.
\end{abstract}

Keywords: raised bog, microclimate, water table level.

\section{INTRODUCTION}

Peatlands occupy 463.2 Mha around the world and are a site of carbon accumulation of global significance [Leifeld \& Manicheti, 2018]. Due to their specific habitat conditions, they are also the areas with specialised plant and animal species that are generally absent in other habitats [Malec et al., 2016; Minayeva et al., 2017]. In Poland, peatlands occupy about $0.6 \%$ of the country, of which only $4.4 \%$ are raised bogs [Ostrowski et al., 1995]. Many peatlands are or have been used to acquire peat for the horticultural and balneological purposes, and in the past for heating as well. Reclamation of the post-mining areas to restore the peat-formation process is difficult and time-consuming, and such measures require appropriate hydrological conditions enabling the growth of the peat-forming vegetation, especially bryophytes of the Sphagnum genus [Słowińska et al., 2010; Gonzáles \& Rochefort 2014]. Hydrological processes are strongly linked to the microclimate [Davis et al., 2019].

A microclimate is the climate of a small area, from several to several hundred square metres [Niedźwiedz, 2006]. It reflects the extremely local, very minor effect of the environment on the atmospheric conditions in the ground layer of air 
a)

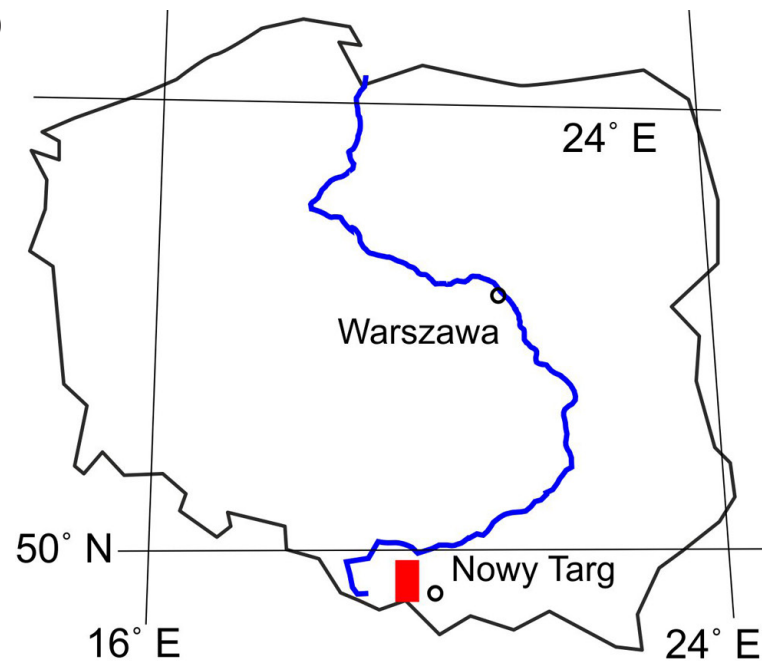

b)

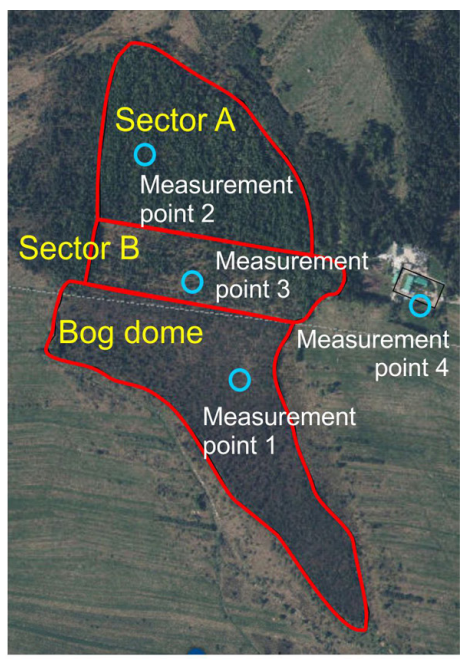

Figure 1. Location of the Bór za Lasem bog in Poland (a) and the location of measurement points in the research areas (b)

(up to $2 \mathrm{~m}$ ) [Chen et al., 1999; Niedźwiedz, 2006]. The microclimate of specific areas is characterised based on horizontal and vertical gradients, primarily of temperature and humidity. They are described using instantaneous measurements of the air temperature and humidity profile, as well as wind speed or the daily course of temperature and humidity during sunny and windless weather [Paszyński et al., 1999; Niedźwiedź, 2006; Chen et. al., 1999]. The microclimatic differences are largely determined by the albedo, heat capacity, and moisture level of the substrate, the shape of the terrain, and vegetation cover [Caputa \& Leśniok, 1999]. In the case of forest communities, we can distinguish the microclimate of the undergrowth and that of the active surface, i.e. the outer surface, of the tree crowns.

The aim of the study was to assess the hydrological and microclimatic parameters in the areas at different stages of succession after the discontinuation of peat extraction relative to the conditions on a natural raised bog. Understanding these conditions is necessary for the effective reclamation of degraded peatlands.

\section{MATERIAL AND METHODS}

\section{Study area}

The study was conducted on the Bór za Lasem raised bog located in the Orawa-Nowy Targ Basin in Poland, which is a depression bordered by mountain ranges to the north and south. The basin is located in a moderately warm vertical climate zone, but has specific climate features, such as pools of cold air and fog and warmer and drier summers than in the surrounding area [Kondracki, 2011].

The area of the Bór za Lasem peat bog is currently 55 ha, the average thickness of the deposit is $1.8 \mathrm{~m}$, and the maximum thickness is $3.65 \mathrm{~m}$ [Lipka \& Zając, 2014]. Peat was extracted (handcut) here for centuries by the local population for its own needs, and from the late 1950s to the early 1990s, it was extracted mechanically on an industrial scale with the block-cutting method. Two sectors, A and B, remained when extraction was discontinued (Figure 1). Sector A has an area of about 16 ha, and the average thickness of the remaining peat is $39.3 \mathrm{~cm}$. The area of sector $B$ is about $8 \mathrm{ha}$, and the average peat thickness is 64.6 cm [Zając et al., 2018a, b].

Following peat extraction, the post-mining areas underwent natural succession. The peat extraction in sector A was discontinued 10 years earlier (in the early 1980s) than in sector B, so they are at different stages of succession. In the older sector A, a pine (Pinus sylvestris) and birch (Betula pendula) woodland has developed, with typical coniferous forest species such as European blueberry (Vaccinium myrtillus), lingonberry ( . vitis-idaea), and bog bilberry ( $V$. uliginosum). The younger sector B is covered primarily with cotton-grass (Eriophorum vaginatum) and ericaceous shrubs, mainly heather (Calluna vulgaris), with a smaller share of bog bilberry and marsh Labrador tea (Ledum palustre). The moss layer is better developed in sector A, where true mosses predominate, while sector $\mathrm{B}$ has a greater share 
Table 1. Mean cover ( $\%$ ) of vegetation in stratification layers and of bare peat $(\%)$ in the two sectors of the post-mining area [Zając et al., 2018a] and on the bog dome

\begin{tabular}{|c|c|c|c|}
\hline Cover & Bog dome & Sector A & Sector B \\
\hline Tree layer & 2 & 11 & 1 \\
\hline Shrub layer & 21 & 10 & 10 \\
\hline Herb layer & 67 & 44 & 80 \\
\hline Moss layer & 72 & 23 & 11 \\
\hline Bare peat & 6 & 18 & 22 \\
\hline
\end{tabular}

of Sphagnum sp. On the dome of the bog, there is raised-bog vegetation with the species characteristic of the Oxycocco-Sphagnetea class, such as Sphagnum mosses, cotton-grass, cranberry (Oxycoccus palustris), bog bilberry, marsh Labrador tea, and bog rosemary (Andromeda polifolia), with mountain pine (Pinus mugo), characteristic of this mountainous region, in the shrub layer. Table 1 presents the area coverage of individual vegetation groups and of bare peat on the dome and in the post-mining sectors. Detailed information can be found in Zając et al. [2018a, b].

\section{Methods}

Three measurement points were designated in the study area: one on the non-degraded dome of the bog (measurement point 1) and two in post-mining areas in different stages of succession (point 2 in sector $\mathrm{A}$ and point 3 in sector $\mathrm{B}$ ). The measurement points in the post-extraction areas were located in the patches of representative vegetation for each habitat, avoiding the vicinity of ditches, stagnant water, and dense groups of trees, and with similar peat thickness (sector A $-56 \mathrm{~cm}$; sector B $-60 \mathrm{~cm}$ ). The water level at the measurement points was continuously recorded using the data loggers (Diver, vanEssen instruments) installed in observation wells. At these points, miniature temperature and humidity loggers (HOBO) were placed in radiation shields, $0.5 \mathrm{~m}$ above the ground. An automatic weather station was situated $300 \mathrm{~m}$ from the bog, where precipitation, temperature, and humidity were measured $2 \mathrm{~m}$ above ground level (measurement point 4) using the same type of sensor (HOBO) as at the other points. Temperature and humidity were recorded every hour. The meteorological elements and the water table level were measured in the warm half of the year 2016, i.e. from May to October.
The microclimate was analysed during the summer months (June-August). For this purpose, seven characteristic days were selected for the analysis - five days with sunny weather and two with cloudy weather. The interaction of the environmental elements is most evident in the ground layer of air from 0 to $2 \mathrm{~m}$ during sunny and windless weather, which is reflected in the values and course of temperature and humidity over time. In the case of cloudy, windy or rainy weather; however, the microclimatic differences become blurred. Therefore, the choice of days for quantitative characterisation of the microclimate was guided by the type of weather, which was identified on the basis of the daily extreme temperatures and humidity values and the calendar of synoptic conditions developed for southern Poland by Niedźwiedź [2017].

The basic statistics were calculated for the meteorological parameters and water table level, i.e. means, extreme values, and standard deviations. The relationships between the daily water level and average air temperature and total precipitation were determined using Spearman's correlation coefficient.

\section{RESULTS}

\section{The course of weather conditions and changes in the water table level}

According to the measurements carried out from $1^{\text {st }}$ May to $31^{\text {st }}$ October 2016 (warm half of the year) at the weather station representing the local climate, the average air temperature during this period was $12.6^{\circ} \mathrm{C}$. The highest maximum temperature, i.e. $36.1^{\circ} \mathrm{C}$ was recorded on $25^{\text {th }}$ June, and the lowest, $-7.9^{\circ} \mathrm{C}$, on $28^{\text {th }}$ October. The precipitation total was $739 \mathrm{~mm}$. The highest rainfall was recorded in the last third of July, and the highest daily rainfall was $57 \mathrm{~mm}$ (Fig. 2).

The course of variation in the location of the water table at each point in relation to the air temperature and precipitation level is shown in Figure 2 . The reaction of the water table (rising or lowering) to the meteorological factors was similar at all sites, with the smallest fluctuations on the dome of the bog and the largest in the post-mining areas. The location of the groundwater table and its amplitude were highest in the post-mining area covered mainly with shrubs (measurement point 2), averaging $8.1 \mathrm{~cm}$ below ground level 


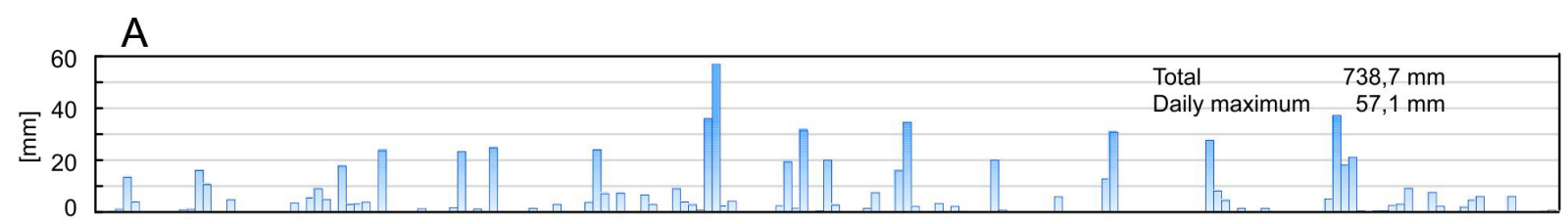

B

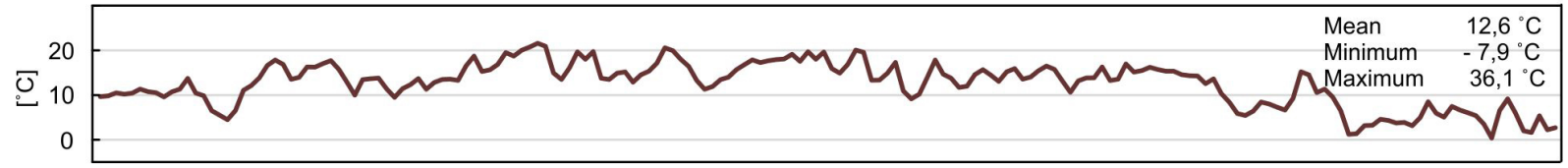

C

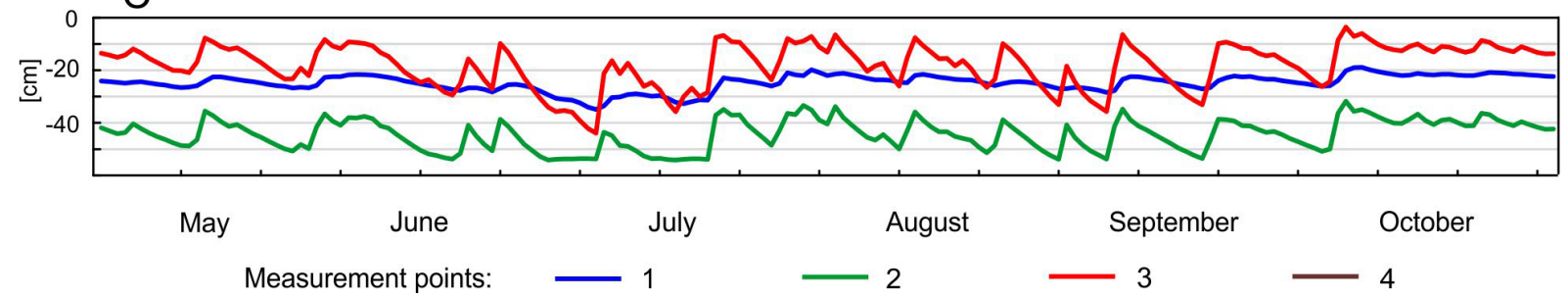

Figure 2. Daily precipitation totals (A), air temperature (B) and location of the ground water table (C) in the warm half of 2016. Measurement points: 1 - Bog dome, 2 - Sector A, 3 - Sector B, 4 - weather station

and $40.3 \mathrm{~cm}$. This was the only site where the area was periodically flooded. The lowest water table (on average $34.4 \mathrm{~cm}$ below ground level) was in the wooded area (point 1), and its amplitude was about half as high as at point 2 . The most stable water table was on the dome of the bog (point 3) - on average $14.9 \mathrm{~cm}$ below ground level, with amplitude of $16 \mathrm{~cm}$ (Table 2).

The lowest water table location and also the highest air temperature and precipitation total during the research period were recorded in July.

The statistically significant relationships (Table 3) were found between the location of the groundwater table and the meteorological elements. This relationship was stronger for the air temperature than for the precipitation total, irrespective of the measuring point. The impact of precipitation on the location of the water table was significant in the post-mining areas, but not on the dome of the bog (Fig. 2, Table 3).

\section{Microclimate characteristics}

Table 4 presents the basic statistical characteristics of the microclimate analysed in the period from June to August 2016, i.e. daily means,

Table 2. Location of the groundwater table at each measurement point in the warm half of 2016 (May-October)

\begin{tabular}{|c|c|c|c|}
\hline \multirow{2}{*}{ Parameter } & \multicolumn{3}{|c|}{ Groundwater level [cm b.g.I] } \\
\cline { 2 - 4 } & $\begin{array}{c}\text { Measurement point 1 } \\
\text { Bog dome }\end{array}$ & $\begin{array}{c}\text { Measurement point 2 } \\
\text { Sector A }\end{array}$ & $\begin{array}{c}\text { Measurement point 3 } \\
\text { Sector B }\end{array}$ \\
\hline Mean & 14.9 & 34.4 & 8.1 \\
\hline Min & 24.9 & 44.1 & -6.4 \\
\hline Max & 8.9 & 21.8 & 33.9 \\
\hline SD & 3.1 & 5.8 & 8.3 \\
\hline Amplitude & 16.0 & 22.3 & 40.3 \\
\hline
\end{tabular}

Explanations: SD - standard deviation.

Table 3. Spearman correlation coefficients between mean daily groundwater level at each measurement point and the mean daily air temperature and daily precipitation total at the weather station in the warm half of 2016

\begin{tabular}{|c|c|c|}
\hline Measurement point & Temperature $\left[{ }^{\circ} \mathrm{C}\right]$ & Daily precipitation total $[\mathrm{mm}]$ \\
\hline 1 - bog dome & $\mathbf{0 . 4 6}$ & -0.11 \\
\hline 2 - sector A & $\mathbf{0 . 4 5}$ & $-\mathbf{0 . 3 1}$ \\
\hline 3 - sector B & $\mathbf{0 . 4 9}$ & $-\mathbf{0 . 3 4}$ \\
\hline
\end{tabular}

Coefficients statistically significant at $\mathrm{p}<0.05$ in bold. 
maximum and minimum values, and amplitudes for temperature and humidity measured in specific types of weather. On the basis of the selected days with weather defined as sunny, the microclimatic conditions were found to be most 'stable' in the post-mining area covered with tree stands (measurement point 2). The smallest amplitudes of both temperature and humidity were found there. The greatest contrasts were noted on the dome of the bog (point 1). In general, at this point the mean and maximum temperatures were higher, the minimum temperature was lower, and the amplitudes, especially of air temperature, were greater than at the other points. In relation to the weather station (measurement point 4), particularly marked differences were observed on the dome for maximum daily temperature and minimum relative humidity on the days with sunny weather (Table 4).

The highest daily temperature amplitude at all sites and at the weather station was found on $8^{\text {th }}$ July under anticyclonic (high-pressure) conditions and during advection of polar maritime old air from the west. Ground frost was observed

Table 4. Values of basic meteorological characteristics of the microclimate at the measurement points on selected days in June-August 2016

\begin{tabular}{|c|c|c|c|c|c|c|c|c|c|c|}
\hline \multirow[t]{2}{*}{ Date } & \multirow[t]{2}{*}{ Parameter } & \multicolumn{2}{|c|}{$\begin{array}{c}\text { Measurement } \\
\text { point } 1 \\
\text { Bog dome } \\
\end{array}$} & \multicolumn{2}{|c|}{$\begin{array}{l}\text { Measurement } \\
\text { point } 2 \\
\text { Sector A }\end{array}$} & \multicolumn{2}{|c|}{$\begin{array}{c}\text { Measurement } \\
\text { point } 3 \\
\text { Sector B } \\
\end{array}$} & \multicolumn{2}{|c|}{$\begin{array}{c}\text { Measurement } \\
\text { point } 4 \\
\text { Weather station } \\
\end{array}$} & \multirow{2}{*}{$\begin{array}{l}\text { Weather type, } \\
\text { synoptic } \\
\text { conditions, } \\
\text { and type of } \\
\text { air mass }\end{array}$} \\
\hline & & $\begin{array}{c}\mathrm{T} \\
\left({ }^{\circ} \mathrm{C}\right)\end{array}$ & $\begin{array}{l}\mathrm{RH} \\
(\%)\end{array}$ & $\begin{array}{c}\mathrm{T} \\
\left({ }^{\circ} \mathrm{C}\right)\end{array}$ & $\begin{array}{l}\mathrm{RH} \\
(\%)\end{array}$ & $\begin{array}{c}\mathrm{T} \\
\left({ }^{\circ} \mathrm{C}\right)\end{array}$ & $\begin{array}{l}\mathrm{RH} \\
(\%)\end{array}$ & $\begin{array}{c}\mathrm{T} \\
\left({ }^{\circ} \mathrm{C}\right)\end{array}$ & $\begin{array}{l}\mathrm{RH} \\
(\%)\end{array}$ & \\
\hline \multirow{4}{*}{2.07 .2016} & Mean & 20.0 & 72.1 & 18.9 & 75.1 & 19.3 & 73.4 & 19.7 & 75.5 & \multirow{4}{*}{$\begin{array}{l}\text { Sunny, hot } \\
\text { Bc-PPmc }\end{array}$} \\
\hline & Max & 33.6 & 100.3 & 30.7 & 99.1 & 31.1 & 100.5 & 32.8 & 100.0 & \\
\hline & Min & 5.8 & 31.9 & 8.6 & 34.2 & 6.6 & 34.8 & 7.8 & 38.6 & \\
\hline & Amp. & 27.8 & 68.4 & 22.1 & 64.9 & 24.5 & 65.7 & 24.9 & 61.4 & \\
\hline \multirow{4}{*}{8.07 .2016} & Mean & 14.3 & 68.7 & 13.2 & 70.1 & 14.0 & 70.3 & 14.5 & 67.6 & \multirow{4}{*}{$\begin{array}{c}\text { Sunny, hot, } \\
\text { ground frost at } \\
\text { night } \\
\text { Wa-PPms }\end{array}$} \\
\hline & Max & 28.3 & 100.3 & 24.4 & 99.1 & 28.7 & 100.5 & 29.5 & 100.3 & \\
\hline & Min & -2.0 & 30.4 & 0.7 & 37.2 & -1.1 & 30.4 & -0.2 & 28.9 & \\
\hline & Amp. & 30.3 & 69.9 & 23.7 & 61.9 & 29.8 & 70.1 & 29.7 & 71.4 & \\
\hline \multirow{4}{*}{11.07 .2016} & Mean & 20.1 & 70.5 & 19.5 & 70.8 & 20.0 & 70.9 & 20.6 & 68.6 & \multirow{4}{*}{$\begin{array}{l}\text { Sunny, hot } \\
\text { SWc-PZ }\end{array}$} \\
\hline & Max & 33.2 & 100.9 & 30.3 & 98.7 & 34.0 & 101.2 & 34.0 & 100.0 & \\
\hline & Min & 5.8 & 36.8 & 8.2 & 40.7 & 5.8 & 34.8 & 7.8 & 36.1 & \\
\hline & Amp. & 27.4 & 64.1 & 22.1 & 58.0 & 28.2 & 66.4 & 26.2 & 63.9 & \\
\hline \multirow{4}{*}{5.08 .2016} & Mean & 19.7 & 76.1 & 19.1 & 78.5 & 19.3 & 78.6 & 19.6 & 77.8 & \multirow{4}{*}{$\begin{array}{l}\text { Sunny, hot } \\
\text { Sc-PZ }\end{array}$} \\
\hline & Max & 33.2 & 100.9 & 29.5 & 99.8 & 31.5 & 101.5 & 31.9 & 100.3 & \\
\hline & Min & 7.8 & 34.8 & 10.6 & 37.7 & 8.6 & 38.2 & 10.2 & 35.6 & \\
\hline & Amp. & 25.3 & 66.1 & 18.9 & 62.1 & 22.9 & 63.3 & 21.7 & 64.7 & \\
\hline \multirow{4}{*}{ 28.08.2016 } & Mean & 16.8 & 77.0 & 16.7 & 76.4 & 16.2 & 79.1 & 16.5 & 79.2 & \multirow{4}{*}{$\begin{array}{l}\text { Sunny, hot } \\
\text { SWa-PZ }\end{array}$} \\
\hline & Max & 32.8 & 100.6 & 29.9 & 100.1 & 31.5 & 101.8 & 31.9 & 100.7 & \\
\hline & Min & 3.7 & 32.8 & 6.2 & 35.2 & 4.2 & 34.8 & 5.4 & 36.1 & \\
\hline & Amp. & 29.0 & 67.8 & 23.7 & 64.9 & 27.4 & 67.0 & 26.5 & 64.6 & \\
\hline \multirow{4}{*}{ 2.06.2016 } & Mean & 9.5 & 96.6 & 9.5 & 96.6 & 9.5 & 97.6 & 10.0 & 93.9 & \multirow{4}{*}{$\begin{array}{l}\text { Cloudy } \\
\text { Bc- PPms }\end{array}$} \\
\hline & Max & 15.6 & 100.3 & 14.5 & 99.1 & 14.5 & 100.2 & 15.2 & 99.0 & \\
\hline & Min & -0.2 & 88.9 & 1.2 & 89.9 & 1.2 & 91.3 & 2.9 & 79.1 & \\
\hline & Amp. & 15.8 & 11.4 & 13.3 & 9.2 & 13.3 & 8.9 & 12.3 & 19.9 & \\
\hline \multirow{4}{*}{22.08 .2016} & Mean & 12.8 & 98.3 & 12.7 & 98.7 & 12.8 & 100.0 & 13.1 & 97.1 & \multirow{4}{*}{$\begin{array}{l}\text { Cloudy with rain } \\
\text { Na-PPm }\end{array}$} \\
\hline & Max & 14.9 & 100.9 & 14.1 & 99.8 & 14.5 & 101.8 & 15.2 & 100.3 & \\
\hline & Min & 11.4 & 92.6 & 11.8 & 94.7 & 11.8 & 95.6 & 11.8 & 86.4 & \\
\hline & Amp. & 3.5 & 8.3 & 2.3 & 5.1 & 2.7 & 6.2 & 3.5 & 13.9 & \\
\hline
\end{tabular}

Explanations: T - air temperature, RH - relative humidity. Synoptic conditions: cyclonic (low-pressure) conditions: $\mathrm{Bc}-$ low pressure trough (non-directional), Sc - advection of air from the south, SWc - advection of air from the southwest; anticyclonic (high-pressure) conditions: $\mathrm{Na}$ - advection of air from the north, Wa advection of air from the west, Swa - advection of air from the southwest. Air masses: PPmc - polar maritime warm, PPms - polar maritime old, PZ - tropical, PPm - polar maritime (Niedźwiedź, 2017). 
Cloudy day

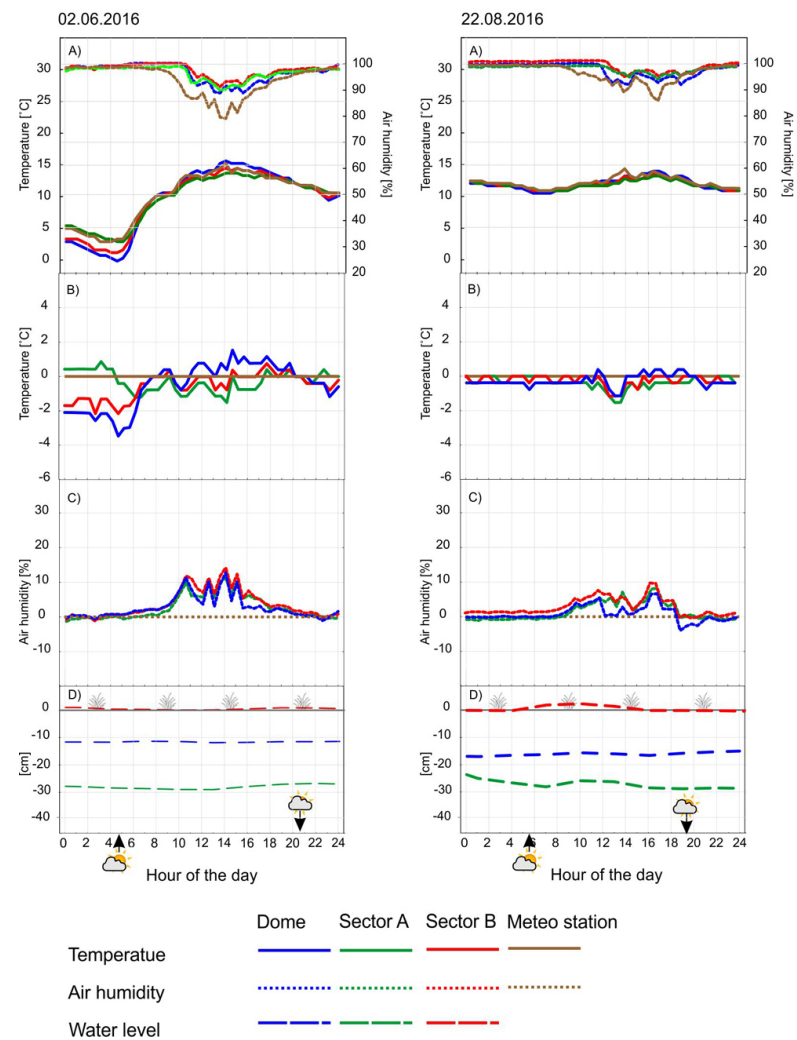

Sunny day
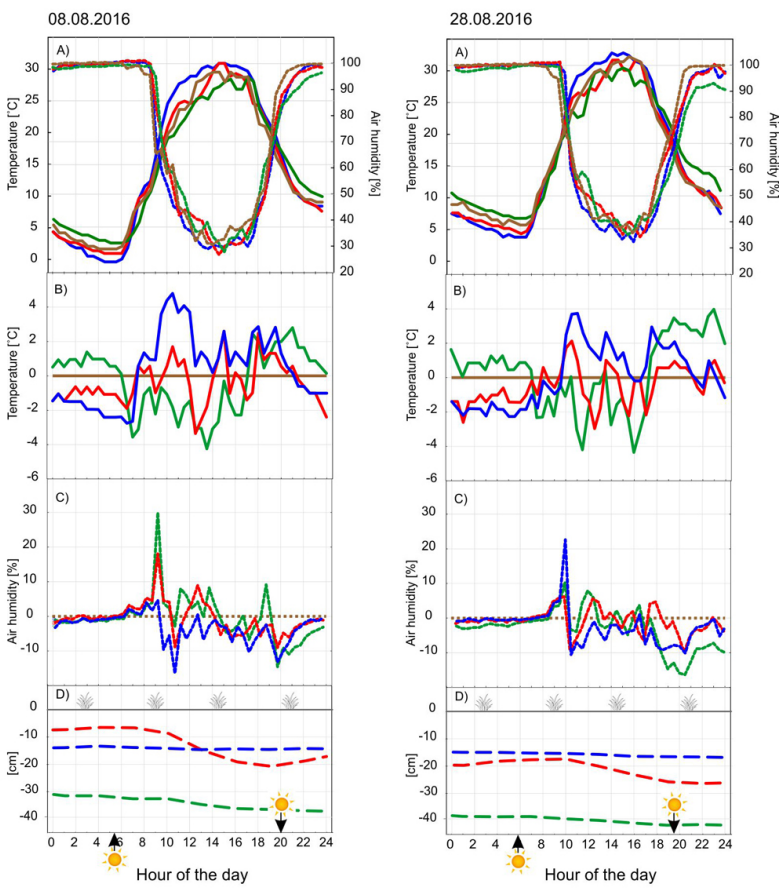

Figure 3. Daily course of temperature and relative humidity at the measurement points and at the weather station (A); deviations of daily temperature (B) and relative humidity (C) in relation to the weather station; location of the groundwater table (D) on selected days with a specific type of weather

on that day. The lowest minimum temperature was recorded on the dome $\left(-2.0^{\circ} \mathrm{C}\right)$, and no negative temperature values were recorded only in the wooded post-mining area (measurement point 2). Similar patterns were noted on the other days, i.e. $2^{\text {nd }}$ and $11^{\text {th }}$ July as well as $5^{\text {th }}$ and $28^{\text {th }}$ August. In the case of cloudy ( $2^{\text {nd }}$ June) and rainy ( $22^{\text {nd }}$ August) weather, the variation in microclimate elements was smaller than during days with sunny weather, including in relation to the measurements at the weather station (Fig. 3 C, D). The smallest daily temperature and humidity amplitudes were then noted at the site with the tree stand (point 2).
Taking into account the entire summer (June-August), no statistically significant relationship was found at any point between the location of the water table and the air temperature, and the relationships between the location of the water table and the precipitation total and humidity were statistically confirmed only in the post-mining areas (Table 5). However, the analysis of the selected days with a specific type of weather showed that the water level responded to the course of temperature changes (Fig. 3). On the days with sunny weather, the water level was lower and fluctuated during the day, especially in the post-mining area covered

Table 5. Spearman correlation coefficients between mean daily groundwater level and mean daily air temperature and relative humidity at the measurement points and total daily precipitation at the weather station during the summer months (June-August) of 2016

\begin{tabular}{|c|c|c|c|}
\hline Measurement point & Temperature $\left[{ }^{\circ} \mathrm{C}\right]$ & Relative humidity [\%] & Daily precipitation total [mm] \\
\hline 1 - bog dome & 0.13 & -0.20 & -0.16 \\
\hline 2 - sector A & 0.11 & $-\mathbf{0 . 3 2}$ & $-\mathbf{0 . 4 7}$ \\
\hline 3 - sector B & 0.19 & $-\mathbf{0 . 3 4}$ & $-\mathbf{0 . 4 3}$ \\
\hline
\end{tabular}

Coefficients statistically significant at $\mathrm{p}<0.05$ in bold. 
with shrubs (measurement point 3), and to a lesser extent in the wooded area (measurement point 2), while the water level on the dome showed no reaction. On the days with cloudy weather, no effect of the changes in temperature or humidity on water level fluctuations was observed at any of the measurement points.

\section{DISCUSSION}

Peat extraction and subsequent transformations of the hydrophysical and chemical properties of the substrate, together with the associated plant succession, significantly influenced the water level and microclimate of the post-mining areas on the peat bog. The differences in the hydrological conditions in these areas compared to those in a natural bog are due to many interrelated factors [Chen et al., 1999].

The air temperature throughout the warm half of the year significantly influenced the groundwater levels, as it is the main factor directly affecting evapotranspiration [Bridgham et al., 1999; Chen et al., 1999]. The effect of the amount of rainfall on the water level proved significant in the postmining areas, but not significant for the dome of the bog. The top layer of peat (the acrotlem), consisting of live and slightly decomposed Sphagnum mosses, has a very high specific yield, determining the water properties of the bog. This minimises the changes in the water level in response to the withdrawal or addition of water [Price, 1996]. The rate of evaporation from the moss surface can be about twice that from a free-water surface, but only if the water level is high [Nichols and Brown, 1980]. At lower water levels, the drying peat layer prevents evaporation because capillary rise is limited [Kettridge et al., 2013]. Sławińska et al. [2010] report a similar significant effect of air temperature and a much weaker effect of rainfall on the water level, while in the central part of the bog, a well-preserved Sphagnum mire, the effect was insignificant.

In the post-mining areas, the upper peat layer has been removed. The remaining peat is usually highly decomposed, with lower water capacity and low thickness. Its hydrophysical properties are different as well, because following drainage, peat undergoes decomposition and mineralisation, which changes the structure of the pores [Okruszko, 1995], increasing the proportion of micropores and reducing that of macropores.
This affects how water is stored in peat and the possibility of water infiltration [Price, 1996]. Therefore, large fluctuations in the water level are typical in the areas where peat has been extracted [Schouwenaars, 1993].

In the post-mining areas, the area coverage by vascular plants is an additional important factor affecting the microclimate and fluctuations in the water level. In contrast to Sphagnum mosses, these plants are able to absorb water from greater depths through their roots and to utilise the water from some of the micropores [Schouwenaars, 1993]. The impact of vegetation on the microclimate, water level, and its fluctuations is associated with the dominant life form of plants. Colonisation of abandoned sites by trees may increase the evapotranspirative losses by as much as $25 \%$ [Price et al., 2003] because trees are able extract water, which is retained by the high tension in the peat [Kettridge et al., 2013], and to significantly lower the water level [Limpens et al., 2014]. The smaller water level fluctuations caused by rainfall in wooded areas are also associated with rainfall interception by the tree layer, which can reach $32 \%$ of rainfall [Price, 2003].

The largest fluctuations in the water level were found in the areas covered by dwarf shrubs (mainly heather). This is due to the absence of an acrotelm and the decreased water capacity of the peat layer remaining after extraction (as on the dome), as well as to the lack of trees reducing the water supply to the surface through direct interception and limiting evaporation from the surface by shading it. Shrubs have a less stabilising effect on water level fluctuations due to their shallower root system and low potential for hydraulic lift [Lafleur et al., 2005; Rewcastle et al., 2020]. In the summer months, in contrast with the entire warm half of the year, no relationship was found between the water level and the air temperature, which is probably explained by the lower temperature amplitude at the sites during that period. However, the analysis of the course of daily changes in microclimatic conditions in different types of weather reveals that the variation in the water level and its fluctuations are largely linked to the variation in the microclimatic conditions in the study areas.

The temperature difference between the research sites is greatest under sunny weather conditions. The primary factor influencing the microclimate is the amount of energy flowing into the surface [Bridgham et al., 1999]. First of 
allm it influences the temperature. The analysis of the daily course of temperature and humidity in the forest habitat (point 2) in relation to the reference conditions (weather station - point 4) shows a lower air temperature during the day and a higher temperature at night. The reverse pattern was found for the changes in air humidity, but in this case the relationships were weaker. This course of microclimatic parameters is typical for forests [Chen et al., 1999; Aussenac, 2000; Kopcińska \& Skowera, 2014; Davis et al., 2019] and is due to the shading effect of trees and to lower air movement [Chen et al., 1999; Aussenac, 2000]. The smallest differences in microclimate in relation to the station were noted in the area covered with dwarf shrubs (measurement point 3 ), because the environmental conditions at this site differ the least from the reference conditions. The comparison of the daily course of changes in the water level with the temperature and humidity at the measuring points reveals a strong relationship for measurement point 3 (shrubs), a weaker one for measurement point 2 (forest), and none at all for measurement point 1 (bog dome).

Under the conditions of lower solar energy supply (cloudy weather), there are no perceptible microclimatic differences between the study areas, and deviations from measurements from the weather station are probably due to the difference in the height at which the measurements were taken $(0.5 \mathrm{~m}$ and $2.0 \mathrm{~m}$ above ground level).

\section{CONCLUSIONS}

1. Weather factors, mainly temperature and precipitation, determine the microclimate and the course of the water level changes through various mechanisms on a natural peat bog and in the post-mining areas in different stages of succession.

2. Under the conditions of an undegraded peat bog, the upper layer, consisting of live and partially decomposed Sphagnum mosses, limits the water level fluctuations by reducing the evaporation from the surface during periods of low water levels, which is caused by a high water storage capacity and reduced infiltration.

3. In advanced stages of secondary forest succession, trees reduce the evapotranspiration from the surface, which reduces the fluctuations in the water level; however, by taking up a large amount of water from the deeper layers, they lower it significantly.

4. The greatest effect of weather conditions on the water level fluctuations occurs at the stage in which the bog is overgrown by shrubs, when there is no natural peat layer (acrotelm), and the impact of shrubs is much smaller than that of trees.

\section{REFERENCES}

1. Aussenac G. 2000. Interactions between forest stands and microclimate: Ecophysiological aspects and consequences for silviculture. Annals of Forest Science, 57, 287-301.

2. Bridgham S.D., Pastor, J., Updegraff, K., Malterer, T.J., Johnson, K., Harth, C., Chen, J. 1999. Ecosystem control over temperature and energy flux in northern peatlands. Ecological Applications, 9, 1345-1358.

3. Caputa Z., Leśniok M. 2009. Struktura bilansu i promieniowania na obszarach miejskich i wiejskich system pomiarowy i wybrane wyniki pomiarów na Wyżynie Śląsko-Krakowskiej. Prace Geograficzne, IGiGP UJ, 122, 23-38.

4. Chen J., Saunders S.C., Crow T.R., Naiman R.J., Brosofske K.D., Mroz G.D., Brookshire B.L., Franklin J.F. 1999. Microclimate in Forest Ecosystem and Landscape Ecology. Variations in local climate can be used to monitor and compare the effects of different management regimes. BioScience 49(4): 288-297.

5. Davis K.T., Dobrowski S.Z., Holden Z.A., Higuera P.E., Abatzoglou J.T. 2019. Microclimatic buffering in forests of the future: the role of local water balance. Ecography, 42, 1-11.

6. González E., Rochefort L. 2014. Drivers of success in 53 cutover bogs restored by a moss layer transfer technique. Ecological Engineering, 68, 279-290.

7. Kettridge N., Thompson D.K., Bombonato L., Turetsky M.R., Benscoter B.W., Waddington J.M. 2013. The ecohydrology of forested peatlands: Simulating the effects of tree shading on moss evaporation and species composition. Journal of Geophysical Research: Biogeosciences, 118, 422-435.

8. Kondracki J. 2011. Geografia Regionalna Polski. Wydawnictwo Naukowe PWN. Warszawa.

9. Kopcińska J., Skowera B. 2014. The role of relief and land use in shaping thermal conditions of local climate. Electronic Journal of Polish Agricultural Universities, 17(3).

10. Lafleur P.M., Hember R.A., Admiral S.W., Roulet N.T. 2005. Annual and seasonal variability in 
evapotranspiration and water table at a shrub-covered bog in southern Ontario, Canada. Hydrological Processes, 19, 3533-3550.

11. Leifeld J., Menichetti L. 2018. The underappreciated potential of peatlands in global climate change mitigation strategies /704/47/4113/704/106/47 article. Nature Communication 9.

12. Limpens J., Holmgren M., Jacobs C.M.J., Van Der Zee S.E.A.T.M., Karofeld E., Berendse F. 2014. How does tree density affect water loss of peatlands? A mesocosm experiment. PLoS ONE, 9.

13. Lipka K., Zając E. 2014. Stratygrafia Torfowisk Kotliny Orawsko-Nowotarskiej. Wydawnictwo Art-Tekst, Kraków.

14. Malec M., Klatka S., Ryczek M., Kruk E. 2016. Zmiany szaty roślinnej torfowiska wysokiego Baligówka pod wpływem działalności człowieka. Ochrona Środowiska i Zasobów Naturalnych - Environmental Protection and Natural Resources 27, 4(70), 7-11.

15. Minayeva T.Yu., Bragg O.M., Sirin A.A. 2017. Towards ecosystem-based restoration of peatland biodiversity. Mires and Peat, 19(01), 1-36.

16. Nichols D.S., Brown J.M. 1980. Evaporation from a sphagnum moss surface. Journal of Hydrology, 48, 289-302.

17. Niedźwiedź T. 2017. Kalendarz typów cyrkulacji atmosfery dla Polski południowej - zbiór komputerowy. Uniwersytet Sląski, Katedra Klimatologii, Sosnowiec.

18. Niedźwiedź T. (Ed.). 2006. Słownik meteorologiczny. Polskie Towarzystwo Geofizyczne, Warszawa.

19. Okruszko H. 1995. Influence of Hydrological differentiation of fens on their transformation after dehydratation and on possibilities for restoration. [In:] B.D. Wheeler, S.C. Shaw, W.J. Fojt. R.A. Robertson (Ed.): Restoration of temperate wetlands. John Wiley \& Sons, 113-120.
20. Ostrowski J., Okruszko H., Oświt J., Dembek W. 1995. Komputerowa Baza Danych o Mokradłach i Użytkach Zielonych Polski. IMUZ, Falenty.

21. Paszyński J., Miara K., Skoczek J. 1999. Wymiana energii między atmosferą a podłożem jako podstawa kartowania topoklimatycznego. Dok. Geogr. 14, IGiPZ, Warszawa.

22. Price J.S. 1996. Hydrology and Microclimate of a Partly Restored Cutover Bog, Québec. Hydrological Processes, 10, 1263-1272.

23. Price J.S., Heathwaite A.L., Baird A.J. 2003. Hydrological processes in abandoned and restored peatlands: An overview of management approaches. Wetlands Ecology and Management, 11, 65-83.

24. Rewcastle K.E., Moore J.A.M., Henning J.A., Mayes M.A., Patterson C.M., Wang G., Metcalfe D.B., Classen A.T. 2020. Investigating drivers of microbial activity and respiration in a forested bog. Pedosphere, 30, 135-145.

25. Schouwenaars J.M. 1993. Hydrological differences between bogs and bog-relicts and consequences for bog restoration. Hydrobiologia, 265, 7-244.

26. Słowińska S., Słowiński M., Lamentowicz M. 2010. Relationships between local climate and hydrology in Sphagnum mire: Implications for palaeohydrological studies and ecosystem management. Polish Journal of Environmental Studies, 19, 779-787.

27. Zając E, Zarzycki J., Ryczek M. 2018a. Substrate quality and spontaneous revegetation of extracted peatland: case study of an abandoned Polish mountain bog. Mires Peat, 21, 1-14. https://doi. org/10.19189/MaP.2017.OMB.310.

28. Zając E., Zarzycki J., Ryczek M. 2018b. Degradation of peat surface on an abandoned post-extracted bog and implications for re-vegetation. Appl. Ecol. Environ. Res., 16. https://doi.org/10.15666/ aeer/1603_33633. 